\title{
PINÓQUIO E A LEI
}

PINOCCHIO AND THE LAW

PINOCHO Y LA LEY

André Karam Trindade ${ }^{1}$

Henriete Karam²

Resumo: $\mathrm{O}$ artigo, que se inscreve no campo dos estudos de Direito na Literatura, é dedicado à obra As aventuras de Pinóquio, de C. Collodi. Partindo do exame das peculiaridades da literatura infantil e da fortuna crítica, especialmente as leituras propostas de matiz histórico-político-social, busca-se abordar o processo de humanização do protagonista como condição para a sua submissão à lei e sua adesão ao pacto social, privilegiando, mediante a análise dos elementos figurativos relacionados aos confrontos de Pinóquio com a Lei, as representações da administração da justiça e, por consequência, problematizando o caráter meramente coercitivo do direito, de modo a questionar a sua eficácia normativa.

Palavras-chave: direito e literatura; processo de humanização; submissão à lei e pacto social; As aventuras de Pinóquio.

1 Doutor em Teoria e Filosofia do Direito (ROMA TRE/ITÁLIA). Mestre em Direito Público (UNISINOS). Professor do Programa de Pós-Graduação em Direito da IMED. Coordenador do KATHÁRSIS - Centro de Estudos em Direito e Literatura da IMED. Presidente da Rede Brasileira Direito e Literatura (RDL). Produtor Executivo do programa de televisão "Direito \& Literatura" (TV Unisinos e TV Justiça). Advogado. E-mail: andre.karam@imed.edu.br

2 Doutora em Estudos de Literatura (UFRGS). Mestre em Teoria Literária (PUCRS). Professora Convidada do Programa de Pós-Graduação em Letras da UFRGS. Membro da Rede Brasileira Direito e Literatura (RDL). Psicanalista. E-mail: henriete@rdl.org.br 
Abstract: This article, which is part of the field of study of Law in the Literature, is dedicated to the novel The Adventures of Pinocchio, by C. Collodi. Based on an examination of the peculiarities of children's literature, and the literary criticism of the book, especially historical, political and social analyses, this paper seeks to investigate the process of humanization of the protagonist as a condition for his submission to the Law and his inclusion in the social contract. Through an analysis of the figurative elements related to the Pinocchio's confrontations with the Law, it favors the representations of administration of justice and, as a consequence, investigates the merely coercive character of Law, in order to question its regulatory effectiveness.

Keywords: law and literature; humanization process; submission to the law and the social contract; The Adventures of Pinocchio.

Resumen: Este artículo, que pertenece al campo de los estudios de Derecho en la Literatura, está dedicado a la obra Las aventuras de Pinocho, de C. Collodi. A partir del examen de las peculiaridades de la literatura infantil y de la formación crítica, especialmente las lecturas de matiz histórico-político-social propuestas, se intenta abordar el proceso de humanización del protagonista como condición para su sometimiento a la ley y su adhesión al pacto social, privilegiando, mediante el análisis de los elementos figurativos relacionados a los enfrentamientos de Pinocho con la Ley, las representaciones de la administración de la justicia, y por consiguiente problematizando el carácter meramente coercitivo del Derecho, para cuestionar su eficacia normativa.

Palabras clave: Derecho y literatura; Proceso de humanización; Sometimiento a la ley y pacto social; Las aventuras de Pinocho.

INTRODUÇÃO

s clássicos são aqueles livros a respeito dos quais, dificilmente, se ouve estou lendo, mas quase sempre estou relendo. Essa é a primeira das quinze definições de clássico formuladas por Ítalo Calvino ${ }^{3}$.

3 CALVINO, Ítalo. Perché leggere i classici. Milano: Mondadori, 1991. 
Outra delas, a terceira, diz que os clássicos são livros que exercem uma influência particular quando se impõem como inesquecíveis e também quando se ocultam nas dobras da memória, mimetizando-se como inconsciente coletivo ou individual. É por essa e outras razões que também se diz que um clássico jamais se esgota. Ele sempre tem algo a dizer. Ele atravessa o tempo e, portanto, é sempre atual.

No campo dos estudos e das pesquisas em Direito e Literatura, mais especificamente do Direito na Literatura ${ }^{4}$, há uma premissa compartilhada: certas narrativas literárias, sobretudo os clássicos - nesse sentido, por exemplo, Antígona, de Sófocles; O mercador de Veneza, de Shakespeare; Crime e castigo, de Dostoievski; O processo, de Kafka; O estrangeiro, de Camus, apenas para referir algumas das mais lembradas - são mais relevantes para a formação e reflexão dos juristas do que grande parte dos manuais, cursos e tratados jurídicos ${ }^{5}$.

Isso porque a literatura exsurge como um verdadeiro repositório de fontes para a reflexão crítica do Direito. Além disso, serve como importante instrumento mediante o qual ocorre o registro histórico dos valores de determinado lugar ou época, na medida em que suas representações do poder, das instituições, da lei e da justiça, por exemplo, também conformam o imaginário coletivo e social6.

Em suma, os clássicos são, universalmente, reconhecidos por transcenderem os contextos específicos nos quais foram escritos, possibilitando, como expressão viva e singular da cultura, o repensar acerca das diversas manifestações do espírito - especialmente, como é o caso, do Direito -, e chamam atenção por retratarem questões práticas que, ao longo do percurso histórico, afligem, mas permitem aprender, com maior sensibilidade do que boa parte da linguagem, hermética, formalista e geométrica, que caracteriza a dogmática jurídica.

4 Ver, para tanto, POSNER, Richard. Law \& Literature. Cambridge: Harvard University Press, 2009.

5 Cf. TRINDADE, André Karam; GUBERT, Roberta Magalhães. Direito e Literatura: aproximações e perspectivas para se repensar o direito. In: TRINDADE, André Karam; GUBERT, Roberta Magalhães; COPETTI NETO, Alfredo (Org.). Direito \& Literatura: reflexões teóricas. Porto Alegre: Livraria do Advogado, 2008. p. 11-66; e, igualmente, MARÍ, Enrique. Derecho y literatura. Algo de lo que sí se puede hablar pero en voz baja. Doxa - Cuadernos de Filosofia del Derecho, n. 21, p. 251-287, 1998.

6 Sobre o tema, consultar OST, François. Contar a lei: as fontes do imaginário jurídico. São Leopoldo: Unisinos, 2005; e, na mesma linha, TALAVERA, Pedro. Derecho y literatura. Granada: Comares, 2006.

7 CALVO GONZÁlEZ, José. Direito curvo. Porto Alegre: Livraria do Advogado, 2013. 
É esse o exercício que se propõe aqui, elegendo uma obra basilar da literatura infantil ocidental: As aventuras de Pinóquio.

\section{PINÓQUIO E A LITERATURA "INFANTIL"}

A leitura aqui proposta de Pinóquio requer que se explicitem dois pressupostos. O primeiro deles diz respeito ao fato de que a literatura infantil se constitui como gênero no séc. XVII, quando, em decorrência da ascensão dos valores e das instituições burgueses, a criança passa a ser vista como um ser diferente do adulto, com características, indagações e necessidades próprias, devendo, portanto, receber uma educação especial, que lhe possibilite decodificar os valores ético-morais do mundo que a circunda. Em outras palavras, a literatura infantil apresenta, em suas origens, caráter estritamente pedagógico-moralista e surge como veículo disseminador dos valores ideológicos burgueses.

Deve-se considerar, portanto, que, se muitas das obras que hoje compõem o quadro da literatura infanto-juvenil - como As viagens de Gulliver, de J. Swift, Robinson Crusoé, de D. Defoe, e diversas narrativas de J. Verne - eram destinadas, na época em que foram produzidas, ao público adulto, tal não é o caso de Pinóquio ${ }^{9}$. A história do boneco de madeira, escrita por Carlo Collodi ${ }^{10}$ no final do séc. XIX, é originalmente publicada num jornal infantil italiano ${ }^{11} e$, mais de meio século depois, transforma-se num sucesso cinematográfico com a versão fílmica de Walt Disney ${ }^{12}$.

8 Empregar-se-á a forma abreviada Pinóquio, grafada em itálico, para indicar a obra.

9 COLLODI, Carlo. As aventuras de Pinóquio. Tradução de Gabriela Rinaldi. São Paulo: Iluminuras, 2002. Dela foram extraídas todas as citações e, considerando a diversidade de edições, optamos por indicar a numeração de página, antecedida pela do capítulo. Já no idioma original, sugerimos a seguinte edição: COLLODI, Carlo. Le avventure di Pinocchio. Torino: Einaudi, 2002.

10 Pseudônimo de Carlo Lorenzini (Florença, 1826-1890), jornalista e escritor italiano.

11 Os primeiros quinze capítulos foram veiculados no semanário Il Gionarle per i Bambini, de Ferdinando Martini, entre julho de 1881 e janeiro de 1883, sob o título de Storia di un burattino (História de um boneco). Com algumas mudanças, nova divisão dos capítulos e acréscimos, o texto definitivo, que contém trinta e seis episódios, recebe o título Le avventure di Pinocchio e é publicado pela Felice Paggi-Libraio Editore, com ilustrações de Enrico Mazzanti, em 1883.

12 Embora a primeira adaptação para o cinema seja de 1911, um filme mudo, colorido à mão e com cerca de 30 minutos de duração, é o longa-metragem de Walt Disney, de 1940, que entrou para a história, apesar de significativas diferenças em relação ao texto literário. 
Assim, na leitura e na interpretação de Pinóquio, mostra-se indispensável reconhecer a presença de elementos que remetem tanto à adoção quanto à transgressão dos moldes e dos padrões da literatura produzida especificamente para crianças no final do séc. XIX.

Enquanto o primeiro pressuposto remete ao gênero da obra, o segundo é relativo ao seu tema central - um boneco de madeira que se transforma em menino - e

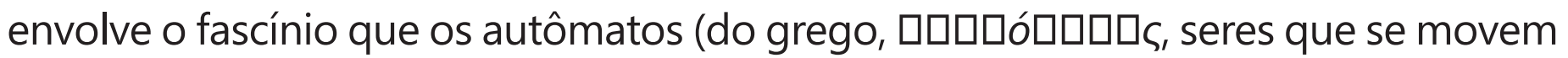
por si mesmos) sempre exerceram sobre o ser humano. Além dos autômatos que povoam o universo mítico - como as serviçais de ouro fabricadas por Hefesto e as estátuas animadas de Dédalo -, historicamente, já no séc. XVI, as cortes europeias se maravilhavam com a visão de figuras mecânicas reais, que se movimentavam, tocavam instrumentos musicais e produziam sons semelhantes a palavras.

O aprimoramento dessas criaturas artificiais, em que o inorgânico imita o orgânico, deve-se ao domínio da mecânica, que além de haver marcado a sociedade seiscentista, deu origem ao pensamento mecanicista - o Zeitgeist que dominou o Ocidente até o séc. XIX e, em seus primórdios, relacionava-se à concepção do universo como uma grande máquina e às ideias de que todos os processos naturais, sendo mecanicamente determinados, podiam ser explicados pelas leis da física e que, uma vez conhecidas as leis de funcionamento do universo, seria possível determinar como ele se comportaria no futuro.

Os filósofos, por sua vez, não se esquivaram de adotar os bonecos automáticos, pelo menos até certo ponto, como modelos para os seres humanos. Ao apresentar aos seus leitores o mecanismo de um relógio como metáfora para o corpo humano, R. Descartes afirma que tal ideia não iria parecer estranha a quem

[...] sabendo quão diversos autômatos, ou máquinas móveis, a indústria dos homens pode construir [...] considerará o próprio corpo como uma máquina que, tendo sido construída pelas mãos de Deus, é incomparavelmente mais ordenada e contém movimentos mais admiráveis do que qualquer das [máquinas] que possam ser inventadas pelos homens ${ }^{13}$.

13 DESCARTES, René. Discurso do método (1637). Tradução de Elza Moreira R. Martins. Brasília, UnB, 1989. p. 74-75. 
A experiência humana proporcionada pelos bonecos mecânicos é transposta da vida real para a literatura dos séculos XVIII e XIX, na qual os autômatos ou seres criados pelo homem tornam-se personagens recorrentes, especialmente das histórias de horror - como é o caso, respectivamente, da boneca Olympia, do conto Der Sandemann, de E. T. A. Hoffmann, e de Frankenstein, personagem do romance homônimo de M. Shelley.

$\mathrm{Na}$ literatura infantil, além de Pinóquio, do soldadinho de chumbo, protagonista do conto de H. C. Andersen, e das conhecidas personagens de O maravilhoso mágico de Oz, de L. F. Baum, encontra-se, bem mais próxima, a revolucionária Emília, do Sítio do pica-pau amarelo, de M. Lobato, boneca de pano que, ao contrário do burat-tino, é firme e categórica em seu desejo de não se tornar gente.

As crianças - talvez menos sensíveis ao Dopplegänger, termo que O. Rank ${ }^{14}$ cunhou para designar o duplo, e ao Unheimlich, a inquietante estranheza investigada por $\mathrm{S}$. Freud ${ }^{15}$, de um lado, e, de outro, mais propensas ao exercício do imaginário - não parecem responder com a mesma angústia que os adultos, quando diante de seres autômatos.

Significativo é que os seres autômatos, quando habitam os universos narrativos da literatura infantil, inscrevem-se no mundo da fantasia e, na literatura adulta, pertencem à dimensão do fantástico, remetendo, do ponto de vista formal e conceitual, às relações entre real e imaginário e, do ponto de vista temático, às características essenciais do homem, com base na diferenciação entre o humano e o não humano - seja essa pautada por uma visão dualista de superioridade do humano, seja por uma visão monística de equivalência existencial entre sujeito e objeto.

São justamente os percursos do não humano ao humano e deste ao advento do sujeito - figurativizados, na narrativa de C. Collodi, através das aventuras vividas por Pinóquio - que interessam, aqui, examinar.

14 RANK, Otto. O duplo (1914). Rio de Janeiro: Coed; Basílica, 1939.

15 FREUD, Sigmund. Lo siniestro (1919). In:

Obras completas. 4. ed. Madrid: Biblioteca Nueva, 1981. v. 3. 


\section{AS MÚLTIPLAS LEITURAS POSSÍVEIS}

Antes, porém, impõe-se apresentar uma breve recensão dos principais estudos, em língua italiana, dedicados à obra de C. Collodi, bem como ressaltar as diferentes leituras que ela tem proporcionado ao longo de 130 anos.

As leituras de matiz historicista põem em evidência o contexto da época em que a obra foi escrita, enfocando seu caráter de sátira política, de denúncia das mazelas sociais e de problematização do sistema educacional italiano.

Superando, em muito, as interpretações de autores como A. Baldini ${ }^{16}, \mathrm{P}$. Pancrazi ${ }^{17}$, M. Boni ${ }^{18}$ e R. Bertacchini ${ }^{19}$ - com as quais dialoga e às quais se opõe -, V. Frosini ${ }^{20}$ levou a cabo a proposta de reler Pinóquio sob as perspectivas política e social21, com uma consciência histórica mais refinada, e considera que a obraprima de C. Collodi não é uma fábula, mas se constitui num mito em que é possível observar o desaparecimento de uma época e, mais precisamente, um ressurgimento de caráter republicano e mazziniano ${ }^{22}$, pois escrito no período em que a história da nação italiana é marcada pela

[...] passagem da idade do Ressurgimento àquela do pósRessurgimento, com o desaparecimento das figuras dominantes da geração ressurgimental, com a profunda transformação social devida à ampliação do sufrágio eleitoral, com o apogeu do chamado transformismo parlamentar e com as primeiras agitações socialistas ${ }^{23}$.

16 BALDINI, Antonio. La ragion politica di Pinocchio (1876). In: Fino ottocento: Carducci, Pascoli, D’nnunzio e minori. Firenze: Le Monnier, 1947.

17 PANCRAZI, Pietro. Vita di Collodi. In: COLLODI, Carlo. Tutto Collodi: per i piccoli e per i grandi. Firenze: Le Monnier, 1948.

18 BONI, Massimiliano. Um saggio e venti capricci su Pinocchio. Bologna: Edim, 1977.

19 BERTACCHINI, Renato (Org.). Le "avventure" ritrovate: Pinocchio e gli scrittori italiani del novecento. Pescia: Fondazione nazionale C. Collodi, 1983.

20 FROSINI, Vittorio. La filosofia politica di Pinocchio. Roma: Edizioni Lavoro, 1990.

21 V. Frosini defende uma nova leitura de Pinocchio com base na publicação do artigo intitulado "A noi I'amaro non ci piace", de Arturo Carlo Jemolo, no qual o autor explora as inúmeras alegorias que a engenhosidade de C Collodi oferece: Pinóquio é o povo italiano; a Fada simboliza o liberalismo progressista; a Raposa e o Gato representam os defensores da monarquia e os clérigos; e o Grilo-falante, marcado pela sua falta de sorte, seria Mazzini. Ver: FROSINI, Vittorio. La filosofia politica di Pinocchio; JEMOLO, Arturo Carlo. A noi I'amaro non ci piace. La stampa, Torino, 6 março 1971.

22 Trata-se de Giuseppe Mazzini, político e revolucionário do Risorgimento, cujos ideais de probidade e de dignidade civil, inspiraram o jovem Carlo Lorenzini.

23 FROSINI, Vittorio. La filosofia politica di Pinocchio. p. 31. 
Ressalta ainda V. Frosini que a história de Pinóquio - “o companheiro das máscaras da comédia de arte, concebido e modelado para divertir a gente, que através do trabalho, do estudo e das experiências assimila a seriedade da vida e se torna homem"24 - só poderia ter sido imaginada por um homem do Ressurgimento e que, para o espírito do Ressurgimento, tal história consistiria num eficaz mito educativo, visto que é escrita no início dos anos 80 do séc. XIX, época em que se verifica uma diferença muito grande entre a Itália como ela é e a Itália como ela deveria ser e na qual o sistema político parecia enfrentar uma crise de decomposição, que era denunciada com veemência nos jornais e nos livros, inclusive em Pinóquio, onde se faz ouvir um "eco da crítica ao costume parlamentar e ao ceticismo político"25.

Outro dos pilares dessa perspectiva historicista é a vinculação da obra às posições político-ideológicas do autor, em especial no que se refere às críticas de C. Collodi às políticas públicas de escolarização. Críticas que são explicitadas tanto na conhecida carta aberta intitulada "Pane e libri", dirigida ao ministro D. Berti ${ }^{26}$, quanto na carta aberta que, atribuída a um florentino e endereçada ao ministro M. Coppino27, encontra-se no artigo "Come studiavano i fiorentini", publicado em Occhi e nasi ${ }^{28}$, e na qual o autor de Pinóquio manifesta sua frontal oposição à Lei Coppino ${ }^{29}$.

Em "Pane e libri", C. Collodi afirma que o sentimento de dignidade humana "entra melhor no sangue à força do pão do que entra no cérebro à força da instrução obrigatória e de livros" e acrescenta:

24 FROSINI, Vittorio. La filosofia politica di Pinocchio. p. 32.

25 FROSINI, Vittorio. La filosofia politica di Pinocchio. p. 32.

26 Domenico Berti foi Ministro da Instrução Pública entre 1865-1867.

27 Michele Coppino foi Ministro da Instrução Pública entre 1876-1879 e 1884-1888.

28 As duas cartas alcançaram maior divulgação ao serem republicadas. A primeira delas consta na coletânea de Pietro Pancrazi (COLLODI, Carlo. Tutto Collodi: per i piccoli e per i grandi) e, também, em COLLODI, Carlo. Gli ultimi fiorentini. Firenze: Nerbini, 2002; a segunda foi editada na coletânea organizada por Daniele Marcheschi (COLLODI, Carlo. Opere. Milano: Mondadori, 1995).

29 Lei que, segundo G. Itzcovich, é considerada uma das mais importantes reformas da esquerda histórica e cujo objetivo não seria, hoje, tema de controvérsias. Registre-se, por oportuno, que tanto a educação quanto a alimentação foram guindadas à condição de direitos (sociais) fundamentais na Constituição brasileira de 1988 (arts. 60, 70, 205, 208 e 227). Da mesma forma, cabe assinalar que é possível perceber, na crítica de C. Collodi, a antecipação dos limites do Estado Social, na medida em que prenuncia a crise de inefetividade das meras declarações de direitos. Ver: ITZCOVICH, Giulio. Pinocchio e il diritto. Materiali per una storia della cultura giuridica. Bologna, ano XXXVII, n. 1, jun. 2007. 
O homem antes de qualquer outra coisa precisa que coma e que beba, que se proteja das intempéries e que tenha um leito onde possa repousar, depois das fatigosas jornadas de trabalho pacientemente suportadas. Então, só então, pode encontrar-se em tal estado de ânimo para dar ouvido à própria consciência e para sentir a ambição de melhorar a si mesmo [...] menos papo furado e mais pão! O proletário maltrapilho e faminto, que não tem para levar à sua família outro alimento além de poucos caules de couve catados no lixo, o que querem vocês que se faça da vossa instrução e dos vossos livros? ${ }^{30}$.

O cerne desses polêmicos escritos de C. Collodi, que recaem sobre a instrução obrigatória, parece consistir numa forma de resistência à disciplina social e teria como fim problematizar, conforme sugere G. Itzcovich, "uma clara questão biopolítica: uma questão sobre o nexo entre saberes e poderes sociais na construção da subjetividade moderna [...] transformar a lenha deformada da humanidade em uma população ordenada, os pinóquios indisciplinados em crianças educadas"31.

O fato é que, na obra de C. Collodi aqui em análise, mostram-se recorrentes tanto a ideia de imposição da escola como atividade obrigatória - na medida em que frequentá-la pareceria constituir uma das condições para a humanização do boneco - quanto as situações em que Pinóquio não tem o que comer ${ }^{32}$.

As questões relativas à educação, que remetem implícita ou explicitamente ao processo de escolarização como objetivo político e tarefa do governo, são, também e em parte, a base das leituras pedagógicas e moralistas de Pinóquio, nas quais sobressai, invariavelmente, a discussão sobre as posições política e religiosa do autor.

Em seu estudo histórico sobre a escola elementar italiana, Ester de Fort ${ }^{33}$ refere que, nos anos da Restauração e do Ressurgimento, o desenvolvimento da educação pública estatal era um programa iluminista, liberal, laico; depois da

30 COLLODI, Carlo. Tutto Collodi: per i piccoli e per i grandi. p. 780-781.

31 ITZCOVICH, Giulio. Pinocchio e il diritto. Materiali per una storia della cultura giuridica. p. 240.

32 M. Ripoli investiga em que medida os juízos formulados por C. Collodi em "Pane e libri" podem ser identificados em Pinóquio e, para isso, toma como base três temas centrais do romance: a fome e a pobreza; os livros e a escola; e a mentira. Ver: RIPOLI, Mariângela. Pinocchio e l'obbligo scolastico. Materiali per una storia della cultura giuridica, Bologna, ano XXX, n. 2, p. 511-524, dec. 2000.

33 FORT, Ester de. La scuola elementare dall'Unita alla caduta del fascismo. Bologna: Il Mulino, 1996. 
unificação da Itália, a instrução pública foi promovida pela esquerda histórica e fortemente desejada pelos extremistas - democratas-republicanos, radicais e socialistas -, embora sofresse forte oposição, feita sobretudo por parte dos católicos e de alguns integrantes do liberalismo.

A esse respeito, mostra-se oportuno evocar as considerações de G. Itzcovich, quando sugere que $C$. Collodi seria um dos representantes da veia realista plebeia que se mantém, na Itália, em pleno séc. XIX e que se caracterizava, entre outras coisas, por não compartilhar a fé - primeiro iluminista e depois positivista - dos magníficos avanços e progressos da educação pública estatal. Segundo ele, o lugar comum popular que se encontra na obra "é o grito e o lamento de Pinóquio: primeiro, o pão, a estrada, a vida; depois, embora também se precise, os abecedários, os professores, os pedagogos"34.

Tal contexto justificaria a tese defendida por R. Mazzucco - no seu sugestivo artigo intitulado /l burattino conservatore - de que Pinóquio é um boneco conservador, para não dizer reacionário e conformista, de tal modo que, a seu ver, o texto de C. Collodi "resulta numa involuntária divulgação de preceitos e costumes impregnados do passado, na obra de um escritor que revela sua verdadeira inclinação de católico conservador"35.

Nessa mesma linha de uma leitura pedagógica de caráter religioso, também merece destaque a posição assumida por P. Bargellini - na conferência Paternità di Carlo Collodi, proferida no Palazzo Vecchio, na cidade de Firenze, em outubro de 1941, e posteriormente incluída no livro intitulado La verità di Pinocchio ${ }^{36}$-, quando sustenta a ideia, embora de modo mais elaborado e sofisticado do que R. Mazzucco, de que o "Pinóquio, assim como todas as obras-primas italianas, apresenta um fundamento baseado na verdade da doutrina católica"37 e justifica sua leitura alegando que a história do burattino tem como pano de fundo as relações entre pai e filho e que as aventuras por eles vividas se estruturam em

34 ITZCOVICH, Giulio. Pinocchio e il diritto. Materiali per una storia della cultura giuridica. p. 239.

35 MAZZUCCO, Roberto. Il burattino conservatore. Tempo presente. Rivista mensile di informazione e discussione, Roma, n. 3-4, v. 8, mar.-apr. 1966. p. 67.

36 BARGELLINI, Piero. La verità di Pinocchio. Brescia: Morcelliana, 1942.

37 MAZZUCCO, Roberto. Il burattino conservatore. Tempo presente. p. 125. 
dois ciclos - de um lado, a perda, ou fuga, do pai; de outro, a redenção, ou o retorno, ao pai -, de tal modo que, a seu ver, a fábula se transforma em um mito religioso, no qual se torna possível encontrar alguns índices bastante pontuais: (a) Pinóquio é filho de um lenhador; (b) sua mãe, a fada, é uma virgem; (c) essa fada, que é uma menina com cabelos azuis, tem um adorno cuja cor é a do manto de Nossa Senhora; (d) depois de inúmeros erros e penitências, Pinóquio alcança a sua regeneração através da Graça.

No que se refere às interpretações que tendem a ver em Pinóquio um texto de ensinamento confessional ${ }^{38}$, é preciso considerar, como muito bem assinala V. Fronsini, que a popularidade alcançada por Pinóquio em países como EUA e a antiga Rússia soviética desmente as tentativas de impor ao texto uma leitura que seja permeada pela apologia dos dogmas católicos - a qual, para o autor citado, contrasta com "a mentalidade histórica e a humanidade de Collodi, cujas concepções políticas, inspiradas em um rigoroso laicismo, estão muito bem documentadas de modo que não deixam margem para quaisquer dúvidas"39.

Além disso, impõe-se levar em conta o caráter mítico de Pinóquio, que, segundo defende V. Frosini na esteira do teórico russo V. Propp, o vincularia por tal peculiaridade ao divino, sendo natural que incorpore os traços de um contexto histórico e geográfico marcado pela tradição do cristianismo e apresente "certos símbolos cristãos tornados tão familiares na cultura e no imaginário social, através de um influxo e uma atração constantes e, talvez, inconscientes"40.

Também em contraste com as interpretações pedagógico-religiosas que procuram imprimir na obra um caráter confessional, pode-se citar a posição adotada pelo pedagogo italiano L. Volpicelli, cujo objetivo principal é enfocar o mito educativo ${ }^{41}$ em Pinóquio. Nas proposições desse autor, observa-se a

38 A leitura mais significativa, nesse sentido, parece ser a interpretação teológica de G. Biffi, cardeal de Bologna, para quem Pinóquio exprimiria completamente os ditames da doutrina católica. Não faltam, por outro lado, estudiosos, como N. Coco e A. Zambrano, que abordam o carater iniciático da obra, examinando os possíves símbolos esotérico-maçônicos. Ver: BIFFI, Giacomo. Contro Mastro Ciliegia: commento teológico a "Le avventure di Pinocchio". Milano: Mondadori, 1998; COCO, Nicola; ZAMBRANO, Alfredo. Pinocchio e i simboli dela "Grande Opera". Roma: Atanòr, 1984.

39 FROSINI, Vittorio. La filosofia politica di Pinocchio. p. 39.

40 FROSINI, Vittorio. La filosofia politica di Pinocchio. p. 41

41 Frontalmente contrário a qualquer visão pedagógica, F. Tempesti, um dos maiores estudiosos de Pinóquio, relaciona a vitalidade e unicidade da obra com o fato de ser um livro infan- 
pertinente tentativa de desvincular a inspiração de C. Collodi de pressupostos espirituais e religiosos ${ }^{42}$, da qual resulta a ideia de que a moral que exsurge em Pinóquio retrata uma sabedoria comum e terrestre, ao contrário das concepções que apregoam uma ética da religião. Tratar-se-ia, para ele, de uma sabedoria que vigorava entre a classe média pós-ressurgimental - portanto, de um momento histórico em que, uma vez feita a Itália, impunha-se fazer seus cidadãos - e que seria capaz de criar um costume que ele define como "um evangelho de proibição moderna que fecha em si os deveres da razão e da religião" 43 , que se fundaria na verdade experimental da vida.

De todos os modos, as perspectivas pedagógicas e moralistas encontram amparo nas observações de B. Croce num artigo que, tendo sido veiculado na revista La Critica do dia 20 de novembro de 1937, foi, posteriormente, incluído na obra Litteratura della nuova Italia e no qual o renomado crítico italiano ressalta que a história de Pinóquio constitui a própria "fábula da vida humana do bem e do mal", uma vez que se trata de "um livro humano, [que] encontra os caminhos do coração... a madeira, com a qual Pinóquio foi feito, é a humanidade"44.

Cabe, entretanto, a ressalva formulada por V. Frosini, em La filosofia politica di Pinocchio, de que, se a obra-prima de C. Collodi assume uma forma exemplar de vida moral, o faz em contraposição implícita ao culto da violência política. Assim, para V. Frosini, "A moral de Pinóquio não é uma moral da interioridade, mas uma moral do tipo social e produtivo, uma moral do trabalho"45; e a Fada seria, na narrativa, a porta-voz de uma concepção de mundo social, que ela propõe a Pinóquio e que sob a forma de um discurso indireto - C. Collodi dirige aos seus leitores.

Para fundamentar tais assertivas, V. Frosini refere o fato de que, na narrativa, é veemente e ameaçador o alerta que a Fada dirige a Pinóquio sobre os riscos do

til cuja estrutura se mostra "perfeitamente privada de intenções pedagógicas" (TEMPESTI, Fernando. Chi era Il Collodi. Com'è fatto il Pinocchio. In: COLLODI, Carlo. Pinocchio. Milano: Feltrinelli, 1972. p. 80).

42 Tal intenção é explicitada já no próprio título do texto, La verità su Pinocchio, em que a partícula su (sobre) vem assinalar a polêmica contraposição às ideias expressas por P. Bargellini no livro La verità di Pinocchio.

43 VOLICELLI, Luigi. La verità su Pinocchio. Roma: Avio, 1954. p. 162.

44 CROCE, Benedetto. Pinocchio. In: Litteratura della nuova Itália. Bari: Laterza, 1939. v. 5. p. 172.

45 FROSINI, Vittorio. La filosofia politica di Pinocchio. p. 42. 
ócio. Pode-se acrescentar que também o Grilo-falante - no qual muitos veem a representação de G. Mazzini ${ }^{46}$ - Ihe faz uma advertência de teor que é bastante semelhante, ao declarar que a vida de vagabundo costuma conduzir ao hospital ou à prisão.

Entre as leituras filosóficas, merecem destaque as formulações de V. FazioAllmayer, que procura oferecer suas considerações sem incorrer no erro de impor a sua leitura ao texto ou de buscar, na intenção do autor, o sentido que se deveria atribuir à obra. Ressaltando que não pretende desvendar o que C. Collodi pensou ao escrever Pinóquio e que se propõe, tão somente, a compartilhar as ideias em si despertadas pela obra, V. Fazio-Allmayer declara: "O valor de Pinóquio está, para mim, no aventuroso processo pelo qual o boneco se faz homem; e, visto que o ser boneco é um modo de ser escravo, a aventura de Pinóquio é aquela de um ser que conquista a própria liberdade"47. Desse modo, este autor, ao contrário de outros estudiosos menos cautelosos, evita, acertadamente, restringir as inúmeras possibilidades de interpretação que a narrativa de C. Collodi pode suscitar.

Já no que se refere às leituras psicanalíticas, poucas são, lamentavelmente, as que não se concentram em aspectos relativos à sexualidade de Pinóquio. Entre os estudos que não se restringem a tal temática, cabe referir alguns. Para $\mathrm{E}$. Garroni ${ }^{48}$, que considera crucial o fato de que C. Collodi tenha escrito a obra em dois tempos, importa investigar, mediante o exame do processo de escrita, em que medida o trágico e cruento final da primeira versão do texto (Pinóquio I), na qual o boneco morre, é transvalorado - sendo, ao mesmo tempo, negado e conservado - no final da segunda versão (Pinóquio II), em que o boneco renasce como ser humano ${ }^{49}$, ao passo que E. Grillandi ${ }^{50}$ explora esse mesmo tema, analisando na obra o conflito entre a pulsão de vida e a pulsão de morte.

46 Ver nota 27, supra.

47 FAZIO-ALLMAYER, Vito. Divagazioni e capricci su Pinocchio. Firenze: Sansoni, 1958. p. 32.

48 GARRONI, Emilio. Pinocchio uno e bino. Roma; Bari: Laterza, 1975.

49 O denominado Pinóquio I corresponde ao texto de Storia di un burattino (História de um boneco), já o Pinóquio II remete à versão definitiva, ou seja, à Le avventure di Pinocchio (As aventuras de Pinóquio). A este respeito, rever o início da nota 6, supra.

50 GRILLANDI, Massimo. Pinocchio e la psicoanalisi. Studi collodiani, Pescia, Fondazione Carlo Collodi, 1976. 
Segundo G. Servadio ${ }^{51}$, a história de Pinóquio é, também, uma história sobre as relações familiares - entre o boneco e seu pai; entre o boneco e a fada que lhe acolhe como uma mãe e/ou irmã - e trata de um tempo psicológico bastante preciso: o da puberdade; enquanto $\mathrm{G}$. Jervis ${ }^{52}$ propõe que a relação do boneco de madeira e o mundo deva ser interpretada com base na ideia de que a compulsão à repetição, verificada em Pinóquio, nasce da relação entre norma e transgressão.

\section{O PROCESSO DE HUMANIZAÇÃO: A SUBMISSÃO À LEI E A ADESÃO AO PACTO SOCIAL}

Abdicando das diversas abordagens possíveis - sejam as que investigam elementos míticos, teológicos ou esotéricos, sejam as que relacionam a concepção da obra com práticas populares, pequeno-burguesa ou libertária, sejam, ainda, as que defendem seu caráter católico-confessional, conservador e reacionário, de um lado, liberal, anarquista ou socialista, de outro -, o que interessa é, tomando como ponto de partida as metáforas da criação que, inscritas na cultura ocidental, o texto incorpora, analisar de que modo a submissão à Lei e a adesão ao pacto social se relacionam com o ingresso no simbólico e, por consequência, com o nascimento do sujeito.

Em Pinóquio, são pelo menos duas as comparações possíveis com narrativas da criação. A primeira delas, referente ao ato da criação do mundo que se encontra no Gênesis, decorre das imbricações entre o criar e o nomear.

Nesse sentido, é possível observar que a escolha do nome do boneco precede sua criação e se configura um ato marcado pela ambivalência, pois o singular significado de que o nome eleito se reveste, para Gepeto, contrasta com sua expressa intenção de bom augúrio: "-Que nome vou dar-lhe? - disse consigo. Quero chamá-lo de Pinóquio. Esse nome vai trazer-lhe sorte. Conheci uma família de Pinóquios: Pinóquio o pai, Pinóquia a mãe e Pinóquios os meninos. $O$ mais rico deles pedia esmola ${ }^{53}$.

51 SERVADIO, Giulio. Psicologia e simbolismo nelle "Avventure di Pinocchio". Studi collodiani, Pescia, Fondazione Carlo Collodi, 1976.

52 JERVIS, Giovanni. Prefazione. In: COLLODI, Carlo. Le avventure di Pinocchio. Torino: Eiunadi, 2002. p. XXIII-XXXVIII.

53 Cap. 3, p. 17, grifos nosso. 
À parte isso, importa destacar o modo como o narrador relata o nascimento de Pinóquio, ou seja, enunciando as partes do corpo do boneco, na medida em que cada uma delas vai sendo esculpida: "começou a trabalhar com afinco, e logo Ihe fez os cabelos, depois a testa, depois os olhos [...] depois dos olhos, fez-lhe o nariz [...] Depois do nariz, fez-lhe a boca [...] Depois da boca, fez-lhe o queixo, depois o pescoço, depois os ombros, o estômago, os braços e as mãos ${ }^{54}$.

Entretanto, ao contrário do que ocorre no mito judaico-cristão apresentado no Gênesis - em que Deus se compraz com o que estava criando -, a experiência de Gepeto não é de satisfação, visto que o boneco, com plena autonomia de sentimento e de ação, demonstra irreverência e age malcriadamente já no ato de sua criação: os olhos de Pinóquio fitam obstinadamente Gepeto, a ponto de incomodá-lo; sua boca, nem fora terminada, começa a rir, a caçoar e a mostrar a língua; as mãos arrancam a peruca do velho; os pés lhe acertam um chute na ponta do nariz...

Observe-se, portanto que, no contexto da obra de C. Collodi, não se trata apenas da autonomia do objeto criado - a qual atinge seu clímax com a fuga de Pinóquio -, mas de "modos insolentes e zombadores" que deixam Gepeto "triste e melancólico, como nunca estivera antes na vida", levando-o a advertir o boneco e a se autocensurar.

Assim, se a decepção que Pinóquio provoca em seu criador decorre do exercício do livre arbítrio, este só poderia encontrar paralelo, no texto bíblico, com a ação de insubordinação que, praticada por Adão e Eva, teria resultado na expulsão do paraíso. Nesse caso, deve-se considerar: (1) que a casa de Gepeto está longe de ser um paraíso; (2) que não ocorre a expulsão, mas a fuga do boneco; e (3) que a efetiva ação repressora de Gepeto só se dá em razão da fuga de Pinóquio.

A segunda possível comparação com narrativas da criação remete à origem do humano que se encontra expressa tanto no Gênesis quanto na fábula de Esopo - com base na qual M. Heidegger constrói sua alegoria do cuidado ${ }^{55}$. Se, em ambos, a condição existencial humana mostra-se ligada, originalmente, à ideia 54 Cap. 3, p. 17-19.

55 HEIDEGGER, Martin. Tiempo y ser (1962). Tradução de Manuel Garrido, José Luis Molinuevo e Félix Duque. Madrid: Tecnos, 2006. § 42. 
da matéria - a terra - que é modelada e adquire vida com a intervenção divina, há de se considerar três peculiaridades do texto de C. Collodi. A primeira remete ao fato de que Gepeto não cria um ser humano, mas fabrica um boneco; e a segunda consiste em que não é Gepeto quem dá vida ou espírito à matéria, pois o pedaço de madeira já os possui antes mesmo de ser esculpido. O que conduz à terceira peculiaridade: enquanto nas narrativas da criação do homem, a matéria se transforma após ganhar forma e espírito, pois a terra ou barro modelado e investido de vida torna-se um ser do mundo animal, dotado de inteligência e vontade; no caso de Pinóquio, o pedaço de madeira - que já tem vida, é sensível e fala - recebe a forma humana, mas isso não altera a matéria de que ele é constituído, visto que se trata, explicitamente, de um boneco de madeira.

Assim, a forma, humana, e a essência, o espírito, não implicam a condição humana, que só virá a ser alcançada pelo boneco quando ele se transformar em menino. De tal modo que a alegoria da criação de Pinóquio leva a pensar que a humanidade não é algo concedido, mas uma conquista do próprio indivíduo.

Para examinar tal questão, impõe-se analisar as características desse indivíduo e, no caso de Pinóquio, verifica-se tratar de um indivíduo que apresentaria natureza mista - embora de origem vegetal, tem a mobilidade dos animais ${ }^{56} \mathrm{e}$ suas ações são regidas pela própria vontade - e que deverá realizar um sinuoso percurso até o seu ingresso na cultura.

Investido de vontade própria - livre arbítrio -, predisposto à desobediência ${ }^{57}$ e com comportamentos agressivos e impertinentes, a trajetória de Pinóquio é marcada por constantes movimentos de fuga e de retorno, bem como por uma série de encontros e desencontros por vezes insólitos: seja com os seres que

56 É importante ressaltar, aqui, o modo como a agilidade de Pinóquio é descrita na narrativa: em sua primeira fuga e retorno para casa, ele é comparado a diferentes animais: "andava aos pulos como uma lebre", "corria como um corcel", "um potro que tinha se desvencilhado do dono" (Cap. 3, p. 19); "um cabrito ou uma lebrezinha perseguida pelos caçadores" (Cap. 4, p. 22). Há, ainda, outras situações nas quais as comparações são as seguintes: "ofegante e com a língua de fora, como um cachorro perdigueiro" (Cap. 6, p. 27); "molhado como um pintinho" (Cap. 6, p. 27); "revoltando-se como uma víbora" (Cap. 7, p. 31).

57 Com relação à desobediência, G. Manganelli afirma: "toda vez que Pinóquio fica obediente, estuda e é bem-comportado, nada acontece [...] Portanto, a obediência e o bom comportamento de Pinóquio são incompatíveis com a sua história, com as suas aventuras. Em termos literários, a história é sempre história de uma desobediência; pressupõe um erro, uma deserção da norma, uma condição patológica" (MANGANELLI, Giorgio. Pinocchio: un libro parallelo. p. 146-147). 
procuram refrear sua busca pelo prazer e socializá-lo (Gepeto, o Grilo-falante, a Fada), seja com os que se aproveitam de sua ingenuidade (a Raposa e o Gato) ou, ainda, com aqueles que o escravizam (como o camponês que faz dele seu cão de guarda, o homenzinho que o leva para o "País das Brincadeiras" e o dono do circo em que ele trabalha como burro amestrado).

Além da rebelião e da fuga, também são traços de Pinóquio a voracidade e a curiosidade $^{58}$. Tais características remetem à ação exploratória do mundo e fazem com que o boneco seja igualmente suscetível às tentações e ao arrependimento, pois levado a vivenciar aventuras que resultam, na grande maioria das vezes, de promessas que ele faz, mas não cumpre, e de advertências que lhe são dirigidas, mas ele não ouve ${ }^{59}$.

Pinóquio sabe o que as pessoas que o amam e que ele ama esperam dele, assim como sabe quais são os deveres de um bom menino. Entretanto, sua singular trajetória pareceria proceder tanto da não concretização do seu destino natural quanto da constante negativa de Pinóquio a submeter-se ao destino que Ihe é externamente imposto.

O primeiro destino é evitado quando "um simples pedaço de lenha, daqueles que no inverno colocam-se nas estufas e nas lareiras para acender o fogo e para aquecer os aposentos"60 vai parar na oficina de mestre Cereja, que decide usá-lo para fazer um pé de mesa. Tampouco isso se realiza: angustiado e amedrontado pelo fato de um pedaço de madeira - "como todos os outros e [que], se for jogado no fogo, deve dar para ferver uma panela de feijão"61 - lastimar-se e

58 Embora a fome e a falta de alimentos sejam recorrentes na narrativa e recebam destaque nas leituras que abordam a problemática social, interessa-nos chamar a atenção, aqui, que a voracidade de Pinóquio pode ser vista como representação de sua pulsão de conhecer, de sua ânsia insaciável de in(corpo)ração do mundo ou de introjeção, conforme a teoria kleiniana das relações de objeto. Assim, em Pinóquio, a pulsão epistemofílica - conceito elaborado por S. Freud - apresenta-se associada ao desejo de descobrir o mundo e de extrair prazer de suas experiências "quase humanas". Ver: FREUD, Sigmund. Tres ensayos para uma teoría sexual (1905). In:

Obras completas. 4. ed. Madrid: Biblioteca Nueva, 1981. v. 2; FREUD, Sigmund. Los instintos y sus destinos (1915). In:

Obras

completas. 4. ed. Madrid: Biblioteca Nueva, 1981. v. 2; KLEIN, Melanie. Inveja e gratidão e outros trabalhos (1946-1963). In:

Obras completas de Melanie Klein. Rio de Janeiro: Imago, 1991. v. 1.

59 Atente-se para o fato de que, na pressa de fabricar o boneco, Gepeto se esquece de fazerIhe as orelhas.

60 Cap. 1, p. 11.

61 Cap.1, p. 13, grifo nosso. 
chorar, mestre Cereja o cede, alegremente, para Gepeto, cujas pretensões são assim explicitadas: "- Pensei em fazer eu mesmo um belo boneco de madeira; mas um boneco maravilhoso, que saiba dançar, esgrimir e dar saltos mortais. Com esse boneco quero correr o mundo para ganhar um pedaço de pão e um copo de vinho"62.

Entretanto, as pretensões iniciais de Gepeto também restam irrealizadas - ao menos em parte - visto que, feito o boneco, os seus planos se alteram. Após a primeira fuga de Pinóquio, quando Gepeto retorna para casa e o encontra com os pés queimados, o velho marceneiro se compadece do boneco e passa a tratálo como filho: dispondo-se a mandá-lo para a escola, Gepeto vende sua velha jaqueta de fustão para comprar-lhe uma cartilha. Pinóquio, por sua vez, que parece ter antecipado as novas intenções de Gepeto - pois na noite anterior já havia dito ao Grilo-falante que iria partir na manhã seguinte, porque não queria ir à escola -, promete ao pai ser o mais bonzinho de todos os meninos e ir à escola, a fim de convencê-lo a refazer-lhe os pés, mas irá correr o mundo sozinho, embora ao sair de casa seu destino, bem como sua própria e momentânea determinação, fosse ir para a escola.

É importante assinalar, aqui, a ambivalência e a inconstância verificadas nos comportamentos de Pinóquio, especialmente no que se refere ao querer ou não ser como todos os outros meninos, pois a questão da identidade é central na narrativa e está intimamente relacionada aos múltiplos destinos - naturais, possíveis e realizáveis - de Pinóquio.

Além disso, se estabelece, nessa altura da história, o conflito entre o destino que Gepeto planeja para seu filho e os projetos que Pinóquio traça para si mesmo. Mas, afinal, o que se poderia esperar de um boneco feito para divertir as gentes, senão que ele também queira se divertir...

Nesse sentido, leve-se em conta que é como igual, e não como menino, que as marionetes de Comefogo o reconhecem - diferentemente das outras personagens que ora o designam e se referem a ele como menino, ora como boneco -, dizendo-se seus "irmãos de madeira" e acolhendo-o com "verdadeira

62 Cap. 2, p. 14. 
e sincera fraternidade". Não é à toa, portanto, que o primeiro ato de bravura de Pinóquio se dê em defesa de Arlequim. A tal ato, outros se seguirão, podendo todos ser vistos como etapas de seu processo de humanização.

Mas também sua identidade de boneco se vê constantemente ameaçada, na medida em que, ao longo da narrativa, ele irá incorporar as funções de cão de guarda, será confundido com um peixe e se transformará em burro, antes de tornar-se um menino de verdade ${ }^{63}$.

As experiências vividas por Pinóquio obedecem à dinâmica do romance de aventuras e de folhetim ${ }^{64}$, de modo que as aventuras se sucedem umas às outras, segundo um esquema básico que pode ser descrito nos seguintes termos: promessa, tentação, transgressão e arrependimento.

As promessas de Pinóquio, que são dirigidas a Gepeto, à Fada e a si próprio, consistem em agir como um bom menino, mas, mesmo quando genuínas e verdadeiras, interpõem-se à sua realização alguma situação que desperta a curiosidade do boneco ou que lhe apresenta algum benefício.

No primeiro desses casos, serve como exemplo a música de pífaros e as batidas de bumbo do teatro de bonecos, que o desviam, tanto do caminho que levava à escola, quanto do aparentemente determinado rumo de seus pensamentos:

- Hoje, na escola, quero logo aprender a ler; amanhã, então, aprenderei a escrever; e depois de amanhã aprenderei a fazer contas. Depois, com a minha habilidade, vou ganhar muito dinheiro e, com o primeiro dinheiro que eu embolsar, quero logo fazer para meu pai uma bela jaqueta de tecido. Mas por que estou dizendo tecido? Quero fazê-la toda de ouro e prata e com botões de brilhantes. É isso mesmo que aquele pobre homem merece, porque, afinal, para comprar meus livros e para poder educar-me, ficou de camisa... com este frio! Somente os pais são capazes de fazer certos sacrifícios!... ${ }^{65}$

63 Cabe referir que a transformação de Pinóquio em burro tem sua fonte na tradição literária latina, visto que o mesmo ocorre com a protagonista de $O$ asno de ouro, do comediógrafo latino Apuleio.

64 Trata-se de subgêneros da narrativa literária. O primeiro, muito utilizado na ficção destinada ao público infantil e juvenil, é protagonizado, em geral, por um jovem que se confronta com perigos e eventos extraordinários em ambientes hostis, demonstra bravura e, ao final, é recompensado com valores espirituais ou materiais, regressando são e salvo para casa; enquanto o segundo se caracteriza - tal qual ocorre originalmente com o texto de Pinóquio - por ser publicado em série, nos jornais ou periódicos, de tal modo que o capítulo apresentado em cada número deve constituir um episódio que, produzindo efeito de suspense, interesse e estimule o leitor à leitura do número seguinte.

65 Cap. 9, p. 35. 
Antes de responder ao apelo dos sons vindos do circo, Pinóquio hesita, mas não demora muito para abdicar de sua anterior resolução, reformulando seus planos: "- Hoje vou ouvir os pífaros e amanhã irei à escola; para ir à escola sempre tem tempo"66.

Já o segundo caso - quando Pinóquio deixa de cumprir sua promessa porque acredita que poderá obter algum benefício maior e imediato - pode ser ilustrado com as duas situações em que ele decide acompanhar o Gato e a Raposa ${ }^{67}$.

Quando Ihe é oferecida a oportunidade de multiplicar as quatro moedas de ouro que Ihe haviam sido dadas por Comefogo, Pinóquio lembra-se de Gepeto e novamente hesita, mas, ato contínuo, deixa-se facilmente enganar e torna-se vítima de promessas muito mais falsas ${ }^{68}$ do que as que ele mesmo enuncia.

Na segunda vez em que é interpelado pela Raposa e pelo Gato - depois da tentativa de assalto, durante o qual ele não é capaz de reconhecê-los como os seus agressores, e quando deixa a casa da Fada para ir ao encontro de Gepeto -, Pinóquio é novamente convencido. Já não é a ideia de comprar uma nova jaqueta para seu pai, "toda de ouro e prata e com botões de brilhante" 69 , que o seduz, ele nutre exageradas fantasias de riqueza:

- E se, em lugar de mil moedas, eu encontrasse duas mil nos galhos da árvore?... E se, em lugar de duas mil, eu encontrasse cinco mil? E se, em lugar de cinco mil, eu encontrasse cem mil? Ó! Que belo senhor, então, eu ia tornar-me!... Gostaria de ter um belo palácio, um monte de cavalinhos de madeira e um monte de cocheiras para poder brincar, uma adega de licores e vinhos e uma estante toda cheia de confeitos, de tortas, de panetones, de doces de amêndoas e de panquecas com creme $^{70}$.

As situações descritas são suficientes para explicitar também o modo como se configuram a tentação, a transgressão e o arrependimento, cabendo referir que

66 Cap. 9, p. 35.

67 O mesmo ocorre quando ele recebe o convite para desfrutar da liberdade de que os meninos usufruem no País da Brincadeira e deixa de cumprir a promessa que fizera para a Fada.

68 Aliás, não são apenas o Gato e a Raposa que mentem para Pinóquio. Mesmo a Fada, em algumas situações, falta-Ihe com a verdade e tenta ludibriá-lo. Mas é somente o nariz de Pinóquio que cresce quando ele diz uma mentira.

69 Cap. 12, p. 43.

70 Cap. 19, p. 71. 
a capacidade efabulatória de Pinóquio, aliada à sua ingenuidade e ao excesso de autoconfiança, parecem estar entre os principais fatores que o induzem ao erro de avaliação das situações que se lhe apresentam e o predispõem a ceder às tentações. Ao constatar seus equívocos, entretanto, ele se arrepende de suas ações e, nas situações de perigo ou na iminência da morte, é a Gepeto que, embora ausente, ele dirige seus apelos.

Faz-se importante, entretanto, explicitar que é por meio das aventuras vividas que Pinóquio, pouco a pouco, vai se humanizando, e, no seu processo de humanização, adquirem relevância os atos de bravura que ele pratica. O primeiro deles é, como já apontado, quando ele salva a vida de Arlequim - marionete que Comefogo ameaçava utilizar como lenha para assar o carneiro que iria jantar -, oferecendo-se para ser queimado no lugar do irmão de madeira. Tal gesto rendeu ao boneco as quatro moedas de ouro presenteadas pelo dono do circo, sendo a primeira situação em que Pinóquio é recompensado por haver praticado o que se poderia denominar uma boa ação.

De fato, é como se cada uma de suas ações heroicas o fossem revestindo de uma camada de humanidade, pois - resulte ou não no ganho de uma recompensa concreta - o comportamento do boneco, nesses casos, comprova a assimilação de um valor. Assim, à fraternidade, demonstrada quando Pinóquio oferece sua própria vida em troca da de Arlequim, vêm se somar, entre outros: (1) a honestidade, comprovada quando ele se mostra incorruptível e denuncia o ataque das fuinhas ao galinheiro; (2) a responsabilidade, quando ele socorre o colega que é atingido numa briga, sendo o único dos meninos envolvidos que não foge; (3) a caridade, ao salvar do afogamento o cão mastim, que minutos antes o perseguia a mando dos policiais; (4) o amor filial, quando na fuga do tubarão, carrega seu pai nas costas até o completo exaurimento de suas forças; e, por fim, (5) o trabalho, o estudo e a gratidão, últimos dos valores assimilados, que renderão a Pinóquio a transformação em ser humano. 
Note-se, aliás, que - quando Pinóquio sente pela primeira vez o desejo de tornar-se homem - a Fada já havia vaticinado que tal transformação só seria possível se ele perseverasse na obediência, na sinceridade e na dedicação ao estudo e ao trabalho.

A partir de tal contexto, impõe-se assinalar que a paulativa assimilação dos valores humanos e sociais está relacionada à normatização da conduta e à submissão à Lei, cujo efeito será o ingresso de Pinóquio na cultura, ou seja, a sua adesão ao pacto social.

Mas há, nesse processo de humanização, uma questão de fundo que ainda merece ser abordada: constam, na narrativa, referências explícitas tanto ao bom coração ${ }^{71}$ quanto à falta de coração ${ }^{72}$ de Pinóquio. De igual modo, seus comportamentos impertinentes e irresponsáveis se mesclam à angústia que ele manifesta quando ameaçam matar seu pai, ao desespero que experimenta ao ver Gepeto sendo engolido pelas ondas, bem como à dor e à culpa que demonstra ao se deparar com o túmulo da Menina dos cabelos azuis, cuja morte teria sido causada pelo estado de abandono em que ele a havia deixado.

Tal mescla de sentimentos e de comportamentos remete a pensar que o estado de natureza, em Pinóquio, não está em simetria com a concepção rousseauniana. 71 Quatro são as situações em que se encontra a menção ao bom coração de Pinóquio; (1) o narrador relata a reação do boneco ao perceber que Gepeto estava passando frio, porque vendera sua única jaqueta para Ihe comprar uma cartilha: "sem poder conter o ímpeto do seu bom coração, enlaçou o pescoço de Gepeto e começou a beijá-lo por todo o rosto" (Cap. 8, p. 34, grifo nosso); (2) a Fada, relembrando o desespero de Pinóquio por acreditála morta, Ihe diz: "A sinceridade da sua dor fez-me perceber que você tinha bom coração" (Cap. 25, p. 97, grifo nosso); (3) quando Pinóquio salva o cão mastim, o narrador declara: "no fundo tinha um coração excelente, ficou com pena" (Cap. 28, p. 105, grifo nosso); e (4) no sonho que antecede sua transformação em menino, a Fada diz a Pinóquio: "Graças ao seu bom coração, eu lhe perdoo todas as travessuras que fez até hoje. [...] Tenha juízo no futuro e será feliz" (Cap. 36, p. 152, grifo nosso).

72 Quanto à falta de coração de Pinóquio, três são as alusões: (1) ao retornar para a casa da fada, Pinóquio se autorrecrimina: "- Quantas desgraças me aconteceram... E eu as mereço! Porque sou um boneco teimoso e presunçoso... e quero sempre fazer tudo à minha maneira, sem dar ouvido àqueles que gostam de mim e têm mil vezes mais juízo do que eu! [...] Mas pode haver um menino mais ingrato e sem coração do que eu?..." (Cap. 20, p. 74, grifo nosso); (2) após ser abordado pela Raposa e o Gato, Pinóquio decide segui-los, e o narrador afirma: "acabou fazendo o que fazem todos os meninos sem um pingo de juízo e sem coração" (Cap. 18, p. 68-70, grifo nosso); e (3) ao perceber que está se transformando em burro, Pinóquio se autocensura: "eu sou um boneco sem juízo... e sem coração. Oh! Se eu tivesse um pingo de coração, nunca teria deixado aquela bondosa Fada" (Cap. 32 , p. 127 , grifos nossos). 
Assim como leva a refletir sobre as situações em que o boneco se encontra exposto a uma sociedade que está pronta para corrompê-lo e que, portanto, mostra-se bastante próxima das visões de N. Machiavelli ${ }^{73}$ e de T. Hobbes ${ }^{74}$, seja no que se refere à dominação do outro, seja no que diz respeito ao individualismo exacerbado.

Nesse sentido, mostra-se importante examinar as particularidades das cinco comunidades que figuram na narrativa e pelas quais Pinóquio se move ao longo de suas aventuras ${ }^{75}$, visto que cada uma delas apresenta uma tipificação diferente das relações políticas, jurídicas e sociais e que, no seu conjunto de representações, evidenciam a inspiração satírica de C. Collodi:

1 - a aldeia, não nomeada e que fica próxima à casa de Gepeto, é povoada por seres humanos e obedece a padrões tradicionais e arcaicos: seus habitantes formam uma comunidade fechada e atuam como aparentes justiceiros - prontos a intervir na vida do vizinho e a julgá-lo preconceituosa e apressadamente e seu representante da lei e da ordem se mostra receptivo e suscetível a tais julgamentos, usando-os como parâmetro para a sua compreensão dos fatos e da deliberação;

2 - o Grande Teatro de Comefogo, comunidade formada pelas marionetes e por seu dono, circunscreve-se num espaço saturado de direito, na medida em que seu soberano - ou o magnus homo de que nos fala T. Hobbes ${ }^{76}$ - exercita

73 Cabe evocar, aqui, o modo como N. Machiavelli descreve a natureza humana, ao justificar sua posição de que o Príncipe deveria preferir ser temido a ser amado: "Porque dos homens pode-se dizer, geralmente: que são ingratos, volúveis, simuladores e dissimuladores, tementes ao perigo, ambiciosos de ganho; e, enquanto lhes fizeres bem, são todos teus, oferecem-te o próprio sangue, os bens, a vida, os filhos, [...] desde que a necessidade esteja longe de ti; porém, quando esta se avizinha, revoltam-se" (MACHIAVELLI, Niccolò. Principe (1513). Torino: Einaudi, 1972. Cap. XVII, p. 27).

74 Vale lembrar as fórmulas hobessianas: homo homini lupus (o homem é o lobo do homem) e bellum omnium contra omnes (a guerra de todos contra todos). Quanto à primeira, $\mathrm{T}$. Hobbes a extrai da obra Asinaria (v. 495) do comediógrafo latino Plauto e a utiliza, em Do cidadão, para ilustrar sua concepção de que o ser humano é egoísta, perigoso e ávido de poder (HOBBES, Thomas. Do cidadão (1640). Tradução de Fransmar Costa Lima. São Paulo: Martin Claret, 2006). Já a segunda, é empregada no Leviatã para caracterizar que a autopreservação é a primeira lei natural do homem e para explicitar a natural tendência humana de impor-se sobre os demais (HOBBES, Thomas. Leviatã ou matéria, forma e poder de um estado eclesiástico e civil (1651). Tradução de Claudia Berliner. São Paulo: Martins Fontes, 2003).

75 Também se ocupa de tal tema V. Frosini, que analisa, em seu estudo e sob o enfoque político, apenas três delas. Ver: FROSINI, Vittorio. La filosofia politica di Pinocchio.

76 HOBBES, Thomas. Leviatã ou matéria, forma e poder de um estado eclesiástico e civil. 
uma justiça absoluta, marcada pela causalidade e pela arbitrariedade, como se observa, por exemplo, tanto no modo como ele delibera a execução de Pinóquio e Arlequim quanto na maneira como lhes concede o perdão, suspendendo a lei - calcada num princípio formal de validade - mediante um ato de vontade ligado à noção soberana da exceção;

3 - a cidade de Pega-trouxas é habitada por animais falantes e racionais prováveis descendentes e herdeiros da tradição fabulária esopiana (séc. VI a. C.) -, os quais se dividem, de um lado, na multidão de pedintes envergonhados, formada por trouxas, ingênuos explorados e silentes; e, de outro, em alguns poucos indivíduos espertos, oportunistas e poderosos, que ostentam um patrimônio que evidencia a prática exploratória mediante a qual levam a vida;

4 - a ilha das Abelhas Industriosas, por sua vez, é fundada sobre o valor do trabalho e formada por uma sociedade organizada de forma produtiva e socialmente equilibrada, isto é, uma espécie de comunidade utópica em que triunfa a razão humana: todos trabalhavam, as crianças frequentavam a escola e as relações humanas marcadas pela equidade e pela integração social;

5 - o País das Brincadeiras, por fim, é habitado somente por meninos, dos 8 aos 14 anos de idade, e configuraria uma espécie de paraíso terrestre do imaginário infantil - marcado pela anomia e regido pelo princípio do prazer, visto que a única regra é a de que tudo é permitido e que não há autoridades e tampouco qualquer interdição -, não fosse o fato de que, com o passar do tempo, sua população transformava em burros e como tal era comercializada.

É nesse ponto que se pode colocar em discussão alguns aspectos da obra de C. Collodi que são particularmente pertinentes ao Direito. Isso porque, muito embora Pinóquio não explore uma "história jurídica" - tal como ocorre em outras obras, nas quais o direito ocupa posição de destaque no interior da narrativa ${ }^{77}$-, pode-se identificar com facilidade, na obra de $\mathrm{C}$. Collodi, inúmeras cenas a partir das quais é possível pensar o direito.

Nesse contexto, a leitura ora proposta de As aventures de Pinóquio pode ser enquadrada nos estudos daquilo que se denominou Direito na Literatura (Law 77 Tais relações encontram-se explicitadas em TRINDADE, André Karam; GUBERT, Roberta Magalhães. Direito e Literatura: aproximações e perspectivas para se repensar o direito. 
in Literature $)^{78}$, tendo em vista que a narrativa é marcada: por um constante acerto de contas entre Pinóquio e a lei; e por uma interessante representação da administração da justiça.

Abdica-se, aqui, de enfocar questões de teor jurídico-filosófico, embora se reconheça a pertinência de abordagens que se concentrassem nas possíveis vinculações entre a retórica, a mentira e o discurso jurídico ${ }^{79}$, com base, por exemplo, em formulações de J. Derrida ${ }^{80}$ e de M. Foucault ${ }^{81}$.

\section{PINÓQUIO E SEUS CONFRONTOS COM A LEI}

Com efeito, é de se considerar que são inúmeras as situações em que o direito aparece explicitado em Pinóquio ${ }^{82}$ - seja associado a outros aparelhos disciplinares empregados na Idade Moderna, como hospitais e prisões; seja transfigurado, satiricamente, na lógica interna do seu discurso -, podendo ser identificado como tal, por seu caráter positivo e eficaz, isto é, como sistema normativo, prática e discurso jurídico atravessados por Pinóquio.

Nesse sentido é que se pode propor a análise do direito "em" Pinóquio, no sentido da(s) imagem(ns) da lei que figuram na narrativa de C. Collodi. Para tanto, cabe examinar quatro passagens do texto em que se verifica o confronto de Pinóquio com a lei e nas quais é possível, ainda, observar as representações que são oferecidas da administração da justiçås.

78 Sobre a origem dos estudos de Direito e Literatura, a sua importância e a especificidade de suas diferentes vertentes, bem como o atual quadro atual europeu e estadunidense, ver: MITTICA, M. Paola. O que acontece além do oceano? Direito e literatura na Europa. Anamorphosis - Revista Internacional de Direito e Literatura, n. 1, v. 1, p. 3-36, jan.jul. 2015.

79 Relativamente às relações entre linguagem e poder e à concepção da linguagem jurídica como conjunto de signos que exigem interpretações plurais, ver: VESPAZIANI, Alberto. 0 poder da linguagem e as narrativas processuais. Anamorphosis - Revista Internacional de Direito e Literatura, n. 1, v. 1, p. 69-84, jan.-jul. 2015.

80 DERRIDA, Jacques. História da mentira: prolegômenos. Estudos Avançados, São Paulo, n. 10, v. 27, pa. 7-39, maio/ago. 1996.

81 FOUCAULT, Michel. A verdade e as formas jurídicas. Rio de Janeiro: Nau, 2002; FOUCAULT, Michel. A ordem do discurso. São Paulo: Loyola, 2005.

82 G. Itzcovich, em sua análise jurídica de Pinóquio, corrobora tal afirmativa. Ver: ITZCOVICH, Giulio. Pinocchio e il diritto. Materiali per una storia della cultura giuridica.

83 Estes quatro trechos são também indicados e analisados por V. Frosini. Ver: FROSINI, Vittorio. La filosofia politica di Pinocchio. 
O primeiro trecho localiza-se no início da obra: quando Pinóquio, logo após ter aprendido a caminhar, foge de casa e começa a correr pela rua até esbarrar num policial, que o pega pelo nariz e o entrega a Gepeto. Alertado pelo velho marceneiro de que, ao chegarem em casa, irão acertar as contas, Pinóquio reage, atira-se no chão, negando-se a acompanhá-lo. Alguns transeuntes curiosos interferem, aventando que Gepeto daria uma surra no boneco e o faria em pedaços. Ao ouvir tais acusações, o policial deixa Pinóquio em liberdade e, paradoxalmente, prende o pobre e inocente Gepeto, que - sem palavras para se defender e chorando como uma criança - é mandado para a prisão.

O que de início chama a atenção é a postura magistral, levemente megalômana, bem como a coragem exibicionista, assumida pelo policial, que, no caso, é o representante da lei. Trata-se, entretanto, de uma figura da autoridade que, embora capaz de exercer sua função de proteção social, mostra-se vulnerável à opinião da população e, instigado pela (vontade da) maioria, é induzido a cometer uma injustiça, visto que prende Gepeto sem quaisquer provas das alegações de crueldade a ele imputadas pelos transeuntes, sem investigar os fatos e sem the dar, nem mesmo, a oportunidade de se defender.

Em tal contexto, é interessante observar, ainda, a capacidade de Pinóquio para se beneficiar da comoção social, a força da perniciosa e infundada revolta dos aldeões contra Gepeto e o fato de que sua prisão é apenas mais uma das injustiças que compõem um destino repleto de desventuras sociais.

No segundo trecho, por sua vez, o que ocorre é a prisão do próprio Pinóquio, que, assim como Gepeto, também é inocente. Logo depois de terem Ihe roubado as moedas de ouro, o boneco é tomado pelo desespero e, dirigindo-se à cidade de Pega-trouxas, apresenta-se diante do tribunal, onde denuncia os dois malfeitores que o furtaram. O juiz, após ouvi-lo atentamente, condena-o à prisão. Ao escutar a sentença, Pinóquio fica assombrado e quer reclamar, mas os policiais que o conduzem à cela o previnem de que seria uma perda de tempo.

Na situação narrativa descrita, há duas questões a serem analisadas: a imagem do juiz e a lei por ele aplicada. O juiz é um velho macaco da raça dos gorilas, cuja 
respeitabilidade é indicada, na narrativa, pela referência à sua idade avançada, à sua barba branca e, especialmente, ao uso de óculos de ouro que não têm lentes. A ele é que Pinóquio denuncia a fraude perversa de que fora vítima e, fornecendo o nome, sobrenome e descrição dos assaltantes, pede que seja feita justiça.

O comportamento do juiz parece contraditório: de um lado, ouve o relato do boneco com muita benevolência e, até mesmo, enternecimento; de outro, tão logo este o conclui, decide, sumariamente, enviá-lo para a cadeia.

Nesse contexto, é possível pensar que o enternecimento do juiz não fora sincero ou, ainda, que não passava de uma falsa percepção, visto que, segundo o narrador, ele sofria de um lacrimejamento dos olhos que o atormentava há muitos anos - sendo essa, talvez a razão de sua aparente comoção.

Em qualquer dos casos, resta evidente que tudo não passa de mera encenação - protagonizada pelo juiz -, na qual em que cada um desempenha o seu papel e, ao fim e ao cabo, a justiça resultaria do cumprimento de um simples ritual jurídico. Colabora, para isso, o fato de que é apresentada uma imagem da lei vinculada à desconfiança, desde a natureza símia do juiz - no reino animal, a mais próxima do ser humano - e da hipocrisia que é assinalada pela ausência das lentes em seus óculos, colocados sobre o nariz apenas para lhe conferir uma dignidade fictícia, até o modo como ele exercita as suas funções.

Todavia, deve-se levar em consideração que a lei aplicada é a da cidade de Pega-trouxas, na qual o costume e a legislação vigentes são baseados na trapaça, na fraude e no logro, de tal modo que o teor da sentença prolatada pelo juiz é coerente - "Foram roubadas quatro moedas de ouro deste pobre diabo; pois, então, agarrem-no e ponham-no logo na cadeia"84 -, uma vez que o verdadeiro associal ou antissocial é Pinóquio e, por isso, ele deve ser condenado.

Referindo-se à decisão proferida pelo juiz, G. Manganelli destaca, com ironia, que "Pinóquio é culpado de furto sofrido, delito grave, mas se apresentou espontaneamente à justiça, parece arrependido e, afinal, é réu primário. Agora ele é da mesma raça das ovelhas tosquiadas e das borboletas mutiladas. A condenação não é propriamente uma punição, é uma colocação, uma classificação"85.

85 MANGANELLI, Giorgio. Pinocchio: un libro parallelo. p. 104. 
No terceiro trecho, passados quatro longos meses, Pinóquio ainda se encontra na prisão da cidade de Pega-trouxas. O Imperador concede, então, uma ampla anistia a todos os "patifes" de seu reino. Ocorre que, quando o boneco exige ser libertado, o carcereiro Ihe responde que ele não faz parte da turma dos felizardos, de tal modo que Pinóquio é levado a se declarar um patife para que as portas da cadeia Ihe sejam abertas.

Note-se que, novamente, se está diante do direito "às avessas", que vigora na cidade de Pega-trouxas. Pinóquio sai da prisão em virtude de uma anistia que liberta os patifes do reino e precisa se declarar um deles para ser incluído entre os beneficiados.

De tal modo que Pinóquio obtém sua liberdade - como assinala V. Frosini ${ }^{86}$ não porque a justiça triunfa, mas porque ele aprendeu a jogar as regras do jogo de uma sociedade que beneficia e protege os astutos e os ladrões.

Assim, se a mentira era antes mero produto da imaginação do boneco, fruto de uma tendência infantil a inventar, agora ela assume contornos de astúcia, pois pela primeira vez Pinóquio mente de modo deliberado e funcional.

O quarto trecho, por fim, é marcado novamente pelo confronto com a polícia, que Ihe atribui injustamente a culpa de haver agredido um colega durante uma briga, quando Pinóquio fora o único a permanecer no local para socorrer o menino desmaiado. Embora alegue sua inocência, o boneco é preso e, ao ser conduzido pelos policiais, lembra sua experiência anterior perante o juiz, preferindo empreender fuga a protestar no tribunal. Assim, aproveitando-se de um subterfúgio, Pinóquio engana os policiais e foge em disparada.

Observa-se, desse modo, que Pinóquio é, mais uma vez, vítima de uma injustiça, sendo preso por duas razões: era seu o livro que havia atingido o colega, embora não tivesse sido ele a jogá-lo, e, ao invés de fugir como os outros, ele fora o único que decidira prestar socorro ao ferido. Aliás, dupla injustiça, tendo em vista não só que essa é uma das raras vezes em que Pinóquio fala a verdade, como, também, em que ele não foge - pelo menos de início. 
A fuga, quando ocorre, resulta, diretamente, da descrença que Pinóquio formara em relação à justiça, tornando-se possível graças à esperteza do boneco, que não tem mais medo de policiais, que os engana, adula-os, se faz de bobo e se beneficia da ingenuidade deles.

A lógica aqui assimilada por Pinóquio - e facilmente compreendida pelo leitor - é no sentido de que a justiça prende apenas os inocentes, os que falam a verdade e não são espertos o suficiente para se evadir. O paradoxo é que, desde o início da história, diversas personagens - Gepeto, o Grilo-falante e a Fada tentam ensinar o boneco a não mentir e lhe exigem tal comportamento. Contudo, a experiência de Pinóquio no mundo comprova-lhe justamente o contrário: é o dizer a verdade que o coloca a caminho da prisão.

Ao analisar três dos episódios em que Pinóquio se depara com a lei, E. Garroni ${ }^{87}$ constata a presença dos seguintes movimentos: (a) no primeiro, o policial é apenas um símbolo da justiça, porque exercita uma autoridade casual - privada de princípios -, que não se caracteriza pela força da lei, mas pela lei da força, uma vez que não existe uma norma, mas apenas uma decisão particular e concreta, ad hoc; (b) no segundo, ao contrário do policial, o juiz aplica princípios rígidos, que se apresentam, todavia, de forma inversa - o inocente na prisão -, demonstrando que a justiça não é casual, mas necessária, geral e abstrata; (c) já no último, a justiça ainda é considerada necessária e não casual, mas agora os princípios são colocados no seu devido lugar - o culpado na prisão -, embora sua aplicação em concreto pelos policiais resulte incorreta, de maneira que a justiça, mesmo sendo necessária, volta a ser casual ${ }^{88}$.

Outra questão relevante, no que diz respeito à representação do direito em Pinóquio, resulta do fato de que, embora o direito apareça "às avessas" em

87 GARRONI, Emilio. Pinocchio uno e bino.

88 Aqui, merece destaque a observação de G. Itzcovich, para quem "existe uma força de lei, mas também um procedimento e vale o princípio da res judicata. Ou então: as normas, válidas em abstrato, não se aplicam sozinhas; decisiva é a vontade de quem decide (realismo). Em suma, uma justiça necessariamente casual, inexorável e persecutória, diante da qual a culpa é um destino. Em As aventuras de Pinóquio, o direito está invertido, mas ao seu modo é lógico, e os encontros entre Pinóquio e o direito são uma sequência: não um desenvolvimento, uma progressão na direção de uma tese, mas um círculo que retorna sobre a própria premissa e a convalida" (ITZCOVICH, Giulio. Pinocchio e il diritto. Materiali per una storia della cultura giuridica. p. 249-250). 
diversos trechos da narrativa, ele é apresentado mediante a recorrência a alguns de seus aspectos mais conhecidos, como: o poder disciplinar sobre o corpo, a delimitação da culpa e imposição do castigo.

No que se refere especificamente ao castigo, G. Itzcovich identifica oito episódios que exemplificam as punições injustas ou desproporcionais que recaem sobre Pinóquio ao longo de suas aventuras ${ }^{89}$ e conclui que

a pena nas aventuras é, ao lado do direito, necessária e eficaz - produz penitência e, em última instância, obediência -, mas é também casual e injusta. É necessária e eficaz porque acompanha e, antes, empurra Pinóquio na direção da plena e bela humanidade - se disso se trata do menino educado. A pena exerce uma função disciplinar, corretiva, transformadora: agride o corpo de Pinóquio (o nariz, as pernas, os pés); precipita Pinóquio no buraco negro do fim. E também é casual e excessiva. É uma pena que provoca pena, uma punição que irrita um sentido de justiça comum e suscita solidariedade: uma pena necessariamente injusta ${ }^{90}$.

De fato, a punição e a obediência assumem destaque na leitura que G. Itzcovich oferece de Pinóquio, tendo em vista que sua proposta é de evidenciar que a obra configura um testemunho de resistência às disciplinas - resistência na qual podemos ver, cabe acrescentar, que o impulso e a fuga constituiriam o direito fundamental de Pinóquio.

O autor citado sustenta que a imagem da lei em Pinóquio é a de um direito necessariamente casual - separado da vida e da moral ${ }^{91}$-, injusto, cruel, e

89 São elas: (1) um velho, a quem ele pedira um pedaço de pão despeja-Ihe na cabeça uma bacia de água; (2) Gepeto deixa Pinóquio chorar e se desesperar durante horas, antes de refazer-Ihe os pés; (3) Comefogo o recrimina e ameaça queimá-lo por haver interferido na apresentação das suas marionetes; (4) a Fada também ignora, durante mais de meia hora, o pranto e os gritos do boneco, quando lhe cresce o nariz; (5) o Camponês, de quem Pinóquio intentara furtar dois cachos de uva, o prende e faz dele seu cão de guarda; (6) a Fada se faz passar por morta e coloca em sua lápide que a razão da morte fora ter sido abandonada por seu irmão Pinóquio; (7) a Fada o deixa esperando na rua e passando frio durante uma noite inteira, só ao raiar do dia, Pinóquio é recebido pela Lesma e, ao dizer que tem fome, a Lesma Ihe traz comida feita de gesso, papelão e alabastro; (8) o Diretor da Companhia dos Palhaços chicoteia as pernas do boneco, quando ele se queixa da comida, e volta a chicoteá-lo, muitas vezes, para que aprenda as acrobacias que deverá fazer no espetáculo.

90 ITZCOVICH, Giulio. Pinocchio e il diritto. Materiali per una storia della cultura giuridica. p. 254-256.

91 Segundo G. Itzcovich, "se a imagem do direito em Pinóquio é aquela de um direito necessariamente casual, necessariamente cindido da moral, surge a curiosidade de ver o que é nele 
analisa a obra segundo os binômios punição-obediência e promessa-obrigação, demonstrando que "as promessas são normativas (obrigam), mas não são mantidas (fracassam); as penas são necessárias, inexoráveis e eficazes (transformam o corpo de Pinóquio, o vinculam porque o constrangem à obediência), mas são também arbitrárias e injustas" ${ }^{\prime 2}$.

Assim, em sua análise da estrutura circular de Pinóquio, G. Itzcovich afirma que, na narrativa, a ação não é voltada para uma finalidade e identifica as seguintes séries: culpa, penitência, culpa; promessa, infração, promessa; proposição, tentação, queda, proposição; devoção e culpa.

Os elementos utilizados para estabelecer tais séries são, praticamente, os mesmos que se havia levantado na série que se estabeleceu e que, anteriormente, referiu-se - promessa, tentação, transgressão e arrependimento -, sendo esses elementos os pressupostos que permitem afirmar que as relações entre promessa e obrigação e entre punição e obediência levam da análise do "direito em Pinóquio" ao "direito de Pinóquio"; ou seja, à concepção de direito que, nesse caso, emerge da estrutura narrativa e normativa da obra de C. Collodi, que se caracteriza por não ser teleológica, mas circular, reproduzindo os movimentos de promessa $e$ transgressão e de tentação e arrependimento ${ }^{93}$.

a obrigação jurídica, quando se observa um direito menos institucionalizado e codificado, um direito que não endossa o uniforme de policial ou a toga do juiz e que é menos formal e reconhecível do que direito do Grande Teatro dos Bonecos ou do País das Brincadeiras; quando se constata, portanto, o direito em um sentido de todo genérico, como ordenamento coercitivo e como ordenamento da cooperação social, não diferenciado e distinguível de outras formas de coerção ou modalidade de cooperação, como a família, a escola, o trabaIho e, precisamente, a moral. Aqui, interessa, em suma, uma análise da normatividade e da eficácia das regras sociais tout court, focalizando dois fundamentos ou princípios desta juridicidade absolutamente genérica. Proponho, como guia para exploração do direito em Pinóquio, reencontrar os passos das aventuras em que se articulam e desarticulam a relação horizontal entre promessa e obrigação, bem como a relação vertical entre punição e obediência. Podemos chamá-las, respectivamente, um fundamento privado e outro público da obrigação jurídica - obrigação jurídica e normativa, repito, genéricas, não distinguíveis daquelas de outros ordenamentos coercitivos (que conheçam o nexo entre punição e obediência) ou cooperativos (que conheçam o nexo entre promessa e obrigação)" (ITZCOVICH, Giulio. Pinocchio e il diritto. Materiali per una storia della cultura giuridica. p. 253).

92 ITZCOVICH, Giulio. Pinocchio e il diritto. Materiali per una storia della cultura giuridica. p. 259.

93 Neste sentido, P. Hazard, um dos primeiros críticos literários a se ocupar de Le avventure di Pinocchio, chama a atenção - no artigo intitulado "La littérature enfantine em Italie", publicado originalmente na Revue des Deux Mondes, de 14 de fevereiro de 1914, e posteriormente reeditado na obra Uomini ragazzi e libri - para o fato de que em Pinóquio "a penitência segue de perto a culpa, mas a culpa segue de perto a penitência" (HAZARD, Paul. I caratteri nazionali. L'Italia di ieri. In: Uomini, ragazzi e libri: letteratura infantile. Roma: Armando, 1967. p. 96). 


\section{CONSIDERAÇÕES FINAIS}

Com base no exame realizado de Pinóquio e considerado o todo da narrativa, constata-se que os confrontos com a lei não constituem o fator determinante - e sequer colaboram - seja para o processo de humanização do boneco, seja para a sua adesão ao pacto social. As instituições jurídicas - tais como figuram no livro e acima expusemos - demonstram ser ineficazes nesse sentido: o policial mostrase suscetível à opinião pública e atua arbitrariamente, sem sequer investigar os fatos; o juiz - guardião das promessas, num estado democrático -, inserido numa sociedade corrompida, condena a vítima, imputando-lhe a responsabilidade pelo crime sofrido; o tribunal é tão somente o espaço de ritos processuais sumários; as punições são injustas e desproporcionais; e a "justiça" está a serviço de quem engana, adula e ludibria.

O que se mostra decisivo para as mudanças operadas em Pinóquio é a própria trajetória existencial por ele realizada, com suas aventuras e desventuras, aliada ao crescente sentimento de amor e de devoção que ele nutre por Gepeto e pela Fada, pois é disso que resulta sua submissão à Lei - tal como na fórmula freudiana, em que a renúncia às pulsões decorre do temor de perder o amor dos pais.

A propensão à fuga e a tendência à transgressão parecem se extinguir no final da narrativa. Se antes de ser educado o boneco é, por assim dizer, um menino de rua - indomável e insolente, que se recusa a abdicar do seu prazer imediato e a submeter-se às regras de convívio familiar e social -, com a sua total adesão à ética do trabalho, Pinóquio transforma-se em ser humano.

Suas aventuras podem ser compreendidas, metaforicamente, como o percurso que conduz à renúncia a uma parcela de princípio do prazer - que impulsiona à satisfação imediata - e à aceitação do princípio de realidade, das restrições e dos limites indispensáveis à adaptação à realidade exterior.

Assim, das inúmeras promessas que se encontra em Pinóquio, apenas uma escapa ao destino de fracassar: a promessa da Fada se realiza. Entretanto, é preciso considerar que a transformação final em menino constitui, ao mesmo 
tempo, a recompensa e a pena de Pinóquio: o seu prêmio é a punição capital, isto é, a morte do boneco.

\section{REFERÊNCIAS DAS FONTES CITADAS}

BALDINI, Antonio. La ragion politica di Pinocchio (1876). In: Fino ottocento: Carducci, Pascoli, D'nnunzio e minori. Firenze: Le Monnier, 1947.

BARGELLINI, Piero. La verità di Pinocchio, Brescia: Morcelliana, 1942.

BERTACCHINI, Renato (Org.). Le "avventure" ritrovate: Pinocchio e gli scrittori italiani del novecento. Pescia: Fondazione nazionale C. Collodi, 1983.

BIFFI, Giacomo. Contro Mastro Ciliegia: commento teológico a "Le avventure di Pinocchio". Milano: Mondadori, 1998.

BONI, Massimiliano. Um saggio e venti capricci su Pinocchio. Bologna: Edim, 1977.

CALVINO, Ítalo. Perché leggere i classici. Milano: Mondadori, 1991.

CALVO GONZÁLEZ, José. Direito curvo. Porto Alegre: Livraria do Advogado, 2013.

COCO, Nicola; ZAMBRANO, Alfredo. Pinocchio e i simboli dela "Grande Opera". Roma: Atanòr, 1984.

COLLODI, Carlo. Tutto Collodi: per i piccoli e per i grandi. Apresentação e seleção de Pietro Pancrazi. Firenze: Le Monnier, 1948.

COLLODI, Carlo. Opere. Apresentação e seleção de Daniele Marcheschi. Milano: Mondadori, 1995.

COLLODI, Carlo. As aventuras de Pinóquio. Tradução de Gabriela Rinaldi. São Paulo: Iluminuras, 2002.

COLLODI, Carlo. Gli ultimi fiorentini. Firenze: Nerbini, 2002.

COLLODI, Carlo. Le avventure di Pinocchio. Torino: Einaudi, 2002.

CROCE, Benedetto. Pinocchio. In: Litteratura della nuova Itália. Bari: Laterza, 1939. v. 5.

DERRIDA, Jacques. História da mentira: prolegômenos. Estudos Avançados, São Paulo, n. 10, v. 27, p. 7-39, maio/ago. 1996. 
DESCARTES, René. Discurso do método (1637). Tradução de Elza Moreira R. Martins. Brasília, UnB, 1989.

FAZIO-ALLMAYER, Vito. Divagazioni e capricci su Pinocchio. Firenze: Sansoni, 1958.

FORT, Ester de. La scuola elementare dall'Unita alla caduta del fascismo. Bologna: Il Mulino, 1996.

FOUCAULT, Michel. A verdade e as formas jurídicas. Rio de Janeiro: Nau, 2002.

FOUCAULT, Michel. A ordem do discurso. São Paulo: Loyola, 2005.

FREUD, Sigmund. Tres ensayos para uma teoría sexual (1905). In: Obras completas. 4. ed. Madrid: Biblioteca Nueva, 1981. v. 2.

FREUD, Sigmund. Los instintos y sus destinos (1915). In: Obras completas. 4. ed. Madrid: Biblioteca Nueva, 1981. v. 2.

FREUD, Sigmund. Lo siniestro (1919). In: Obras completas. 4. ed. Madrid: Biblioteca Nueva, 1981. v. 3.

FROSINI, Vittorio. La filosofia politica di Pinocchio. Roma: Edizioni Lavoro, 1990.

GARRONI, Emilio. Pinocchio uno e bino. Roma; Bari: Laterza, 1975.

GRILLANDI, Massimo. Pinocchio e la psicoanalisi. Studi collodiani, Pescia, Fondazione Carlo Collodi, 1976.

HAZARD, Paul. I caratteri nazionali. L'Italia di ieri. In: Uomini, ragazzi e libri: letteratura infantile. Roma: Armando, 1967. p. 95-101.

HEIDEGGER, Martin. Tiempo y ser (1962). Tradução de Manuel Garrido, José Luis Molinuevo e Félix Duque. Madrid: Tecnos, 2006.

HOBBES, Thomas. Do cidadão (1640). Tradução de Fransmar Costa Lima. São Paulo: Martin Claret, 2006.

HOBBES, Thomas. Leviatã ou matéria, forma e poder de um estado eclesiástico e civil (1651). Tradução de Claudia Berliner. São Paulo: Martins Fontes, 2003.

ITZCOVICH, Giulio. Pinocchio e il diritto. Materiali per una storia della cultura giuridica, Bologna, ano XXXVII, n. 1, p. 239-268, jun. 2007.

JEMOLO, Arturo Carlo. A noi I'amaro non ci piace. La stampa, Torino, 6/3/1971. 
JERVIS, Giovanni. Prefazione. In: COLLODI, Carlo. Le avventure di Pinocchio. Torino: Eiunadi, 2002. p. XXIII-XXXVIII.

KLEIN, Melanie. Inveja e gratidão e outros trabalhos (1946-1963). In: Obras completas de Melanie Klein. Rio de Janeiro: Imago, 1991. v. 1.

MACHIAVELLI, Niccolò. Principe (1513). Torino: Einaudi, 1972.

MANGANELLI, Giorgio. Pinocchio: un libro parallelo. Milano: Adelphi, 2002.

MARÍ, Enrique. Derecho y literatura. Algo de lo que sí se puede hablar pero en voz baja. Doxa - Cuadernos de Filosofia del Derecho, n. 21, p. 251-287, 1998.

MAZZUCCO, Roberto. Il burattino conservatore. Tempo presente - Rivista mensile di informazione e discussione, Roma, n. 3-4, v. 8, mar.-apr. 1966.

MITTICA, M. Paola. O que acontece além do oceano? Direito e literatura na Europa. Anamorphosis - Revista Internacional de Direito e Literatura, n. 1, v. 1, p. 3-36, jan.-jul. 2015.

OST, François. Contar a lei: as fontes do imaginário jurídico. São Leopoldo: Unisinos, 2005.

PANCRAZI, Pietro. Vita di Collodi. In: COLLODI, Carlo. Tutto Collodi: per i piccoli e per i grandi. Firenze: Le Monnier, 1948.

POSNER, Richard. Law \& Literature. Cambridge: Harvard University Press, 2009.

RANK, Otto. O duplo (1914). Rio de Janeiro: Coed; Basílica, 1939.

RIPOLI, Mariângela. Pinocchio e l'obbligo scolastico. Materiali per una storia della cultura giuridica, Bologna, ano XXX, n. 2, p. 511-524, dec. 2000.

SERVADIO, Giulio. Psicologia e simbolismo nelle "Avventure di Pinocchio". Studi collodiani, Pescia, Fondazione Carlo Collodi, 1976.

TALAVERA, Pedro. Derecho y literatura. Granada: Comares, 2006.

TEMPESTI, Fernando. Chi era Il Collodi. Com'è fatto il Pinocchio. In: COLLODI, Carlo. Pinocchio. Milano: Feltrinelli, 1972.

TRINDADE, André Karam; GUBERT, Roberta Magalhães. Direito e Literatura: aproximações e perspectivas para se repensar o direito. In: TRINDADE, André Karam; GUBERT, Roberta Magalhães; COPETTI NETO, Alfredo (Org.). Direito \& Literatura: reflexões teóricas. Porto Alegre: Livraria do Advogado, 2008. p. 11-66. 
VESPAZIANI, Alberto. O poder da linguagem e as narrativas processuais. Anamorphosis Revista Internacional de Direito e Literatura, n. 1, v. 1, p. 69-84, jan.-jul. 2015.

VOLICELLI, Luigi. La verità su Pinocchio. Roma: Avio, 1954.

Recebido em: jun/2016 Aprovado em: set2016 